\title{
PARTICIPATION IN THE UNITED STATES DEPARTMENT OF' ENERGY REACTOR SHARING PROGRAM
}

An Annual Report

August 31, 1991 - August 29, 1992

Submitted to:

Department of Energy

Contracts Division Chicago Operations Office 9800 South Cass Avenue

Argonne, IL 60439

Attention:

Renee L. Irwin

Contract Specialist

Submitted by:

R. U. Mulder

Assistant Professor and

Director of Reactor Facility

P. E. Benneche

Reactor Services Supervisor

B. Hosticka

Research Scientist

SEAS Report No. UVA/527277/NEEP92/111

May 1992

PREPARED FOR THE U.S. DEPARTMENT OF ENERGY UNDER GRANT NUMBER DE-FG07-80ER10733

DEPARTMENT OF NUCLEAR ENGINEERING AND ENGINEERING PHYSICS

SCHOOL OF

ENGINEERING 骨

\& APPLIED SCIENCE

University of Virginia

Thornton Hall

Charlottesville, VA 22903 


\section{UNIVERSITY OF VIRGINIA \\ School of Engineering and Applled Science}

The University of Virginia's School of Engineering and Applied Science has an undergraduate enrollment of approximately 1,500 students with a graduate enrollment of approximately 600 . There are 160 faculty members, a majority of whom conduct research in addition to teaching.

Research is a vital part of the educational program and interests parallel academic specialties. These range from the classical engineering disciplines of Chemical, Civil, Electrical, and Mechanical and Aerospace to newer, more specialized fields of Applied Mechanics, Biomedical Engineering, Systems Engineering, Materials Science, Nuclear Engineering and Engineering Physics, Applied Mathematics and Computer Science. Within these disciplines there are well equipped laboratories for conducting highly specialized research. All departments offer the doctorate; Biomedical and Materials Science grant only graduate degrees. In addition, courses in the humanities are offered within the School.

The University of Virginia (which includes approximately 2,000 faculty and a total of full-time student enrollment of about 17,000), also offers professional degrees under the schools of Architecture, Law, Medicine, Nursing, Commerce, Business Administration, and Education. In addition, the College of Arts and Sclences houses departments of Mathematics, Physics, Chemistry and others relevant to the engineering research program. The School of Engineering and Applied Science is an integral part of this University community which provides opportunities for interdisciplinary work in pursuit of the basic goals of education, research, and public service. 
An Annual Report

August 31, 1991 - August 29, 1992

Grant No. DE-FG07-80ER10733

DOE Report No. DOE/ER/10733-11

\title{
PARTICIPATION IN THE UNITED STATES DEPARTMENT OF ENERGY REACTOR SHARING PROGRAM
}

\author{
Submitted to: \\ Department of Energy \\ Contracts Division \\ Chicago Operations Office \\ 9800 South Cass Avenue \\ Argonne, IL 60439 \\ Attention: \\ Renee L. Irwin \\ Contract Specialist \\ Submitted by: \\ R. U. Mulder \\ Assistant Professor and \\ Director of Reactor Facility \\ P. E. Benneche \\ Reactor Services Supervisor \\ B. Hosticka \\ Research Scientist \\ Department of Nuclear Engineering and Engineering Physics \\ SCHOOL OF ENGINEERING AND APPLIED SCIENCE \\ UNIVERSITY OF VIRGINIA \\ CHARLOTTESVILLE, VIRGINIA
}

SEAS Report No. UVA/527277/NEEP92/111

May 1992 
A. Introduction .................... 2

B. Summary of Objectives and Previous

Participation in the DOE Reactor Sharing

Program ....................

B.1 Student Participation in Experiments . . . . . . . . 3

B.2 Research Projects Under the Reactor

Sharing Program ................

C. Availability of Reactor $\ldots \ldots \ldots \ldots \ldots \ldots \ldots \ldots$

D. Possible User Institutions .............. 11

E. Assessment of User Institution Interest . . . . . . . . 13

F. Personnel ..................... 13

G. Estimated Budget $\ldots \ldots \ldots \ldots \ldots \ldots \ldots \ldots \ldots$

\section{ATTACHMENTS}

\section{DISCLAIMER}

This report was prepared as an account of work sponsored by an agency of the United States Government. Neither the United States Government nor any agency thereof, nor any of their employees, makes any warranty, express or implied, or assumes any legal liability or responsibility for the accuracy, completeness, or usefulness of any information, apparatus, product, or process disclosed, or represents that its use would not infringe privately owned rights. Reference herein to any specific commercial product, process, or service by trade name, trademark, manufacturer, or otherwise does not necessarily constitute or imply its endorsement, recommendation, or favoring by the United States Government or any agency thereof. The views and opinions of authors expressed herein do not necessarily state or reflect those of the United States Government or any agency thereof. 


\section{SECTION I}

\section{PARTICIPATION IN THE U.S. REACTOR SHARING PROGRAM $1991-1992$}

\section{A. INTRODUCTION}

The University of Virginia Reactor Facility is an integral part of the Department of Nuclear Engineering and Engineering Physics (to become the Department of Mechanical, Aerospace and Nuclear Engineering on July 1, 1992). As such, it is effectively used to support educational programs in engineering and science at the University of Virginia as well as those at other area colleges and universities. The expansion of support to educational programs in the mid-east region is a major objective.

To assist in meeting this objective, the University of Virginia has been supported under the U.S. Department of Energy (DOE) Reactor Sharing Program since 1978. Due to the success of the program, this proposal requests continued DOE support through August 1993. Specifically, $\$ X X, X X X$ in new funds is requested.

\section{B. SUMMARY OF OBJECTIVES AND UVA'S PARTICIPATION IN DOE'S REACTOR SHARING PROGRAM}

The objective of the DOE supported Reactor Sharing Program is to increase the availability of university nuclear reactor facilities to non-reactor owning educational institutions. The educational and research programs of these user inștitutions is enhanced by the use of the nuclear facilities.

Two specific methods have been used by the University of Virginia Reactor Facility to achieve this objective. First, advanced undergraduate and graduate 
classes from area colleges and universities visit the facility to perform experiments in nuclear engineering and physics which would not be possible at the user institution. Second, irradiation services are made available for unsupported research by faculty and students from user institutions. These two areas are discussed below.

\section{B.1. Student Participation in Experiments and Reactor Facility Tours}

A major portion of the Reactor Sharing Program involves groups of students visiting the Nuclear Reactor Facility as part of a tour or to perform experiments involving the use of radioisotopes. Over 1000 students have participated in these activities. A summary of the colleges and universities participating in this portion of the program is provided in Table 1.

The most common experiments fall into three general areas. These are: Radiation and Radioactive Decay, Radioisotope Applications in Science and Industry, and Reactor Operation. A brief description of several of the available experiments is provided in Table II. In addition, special experiments can be arranged to meet the needs of classes in biology, chemistry and physics.

The use of neutron activation analysis for identification of the elemental composition of materials continues to be the most popular experiment. This is a result of the wide application of neutron activation analysis for research in many areas of science. In addition to learning how to use neutron activation analysis, the students also increase their understanding of radioactive decay and interaction of radiation with matter.

The second most requested experiment involves measurements of the decay of radioactive isotopes. The half-life of various short-lived reactor produced isotopes, 
such as aluminum-28 and magnesium-27, are determined. Also, the decay of one isotope into another radioactive isotope is measured to demonstrate the concept of decay chains.

The University of Virginia supplies background information to the course instructors who use the material to prepare the students for a visit to the Reactor Facility. Once at the Reactor Facility, the students perform experiments under the direction of a reactor staff member or a faculty member.

Most faculty members and students participating in these experiments have stated that they were an important addition to their classes. The positive impact of these experiments is also indicated by the number of classes making repeat visits. 
TABLE 1

\section{Summary of Participation In Laboratorles, Training Sessions and Tours Under the Auspices of the Reactor Sharing Program \\ (September 1978 - April 1992)}

\begin{tabular}{|c|c|c|c|c|}
\hline University or College & $\begin{array}{l}\text { This } \\
\text { year }\end{array}$ & Discipline & $\begin{array}{c}\text { Number of } \\
\text { Visits }\end{array}$ & $\begin{array}{l}\text { Faculty } \\
\text { Contact } \\
\end{array}$ \\
\hline Bridgewater College & * & $\begin{array}{l}\text { Chemistry } \\
\text { Physics } \\
\text { Physics } \\
\text { Physics }\end{array}$ & $\begin{array}{l}1 \\
2 \\
1 \\
4\end{array}$ & $\begin{array}{l}\text { J. Martin } \\
\text { D. Neher } \\
\text { P. Spickler } \\
\text { J. Ulrich }\end{array}$ \\
\hline Emory \& Henry College & & Physics & 1 & C. Nelson \\
\hline Hampton University & & Physics & 1 & K. Han \\
\hline James Madison University & * & $\begin{array}{l}\text { Physics } \\
\text { Physics } \\
\text { Chemistry } \\
\text { Biology }\end{array}$ & $\begin{array}{l}9 \\
1 \\
5 \\
3\end{array}$ & $\begin{array}{l}\text { J. Gordon } \\
\text { R. Serway } \\
\text { D. Downey } \\
\text { M. Gordon }\end{array}$ \\
\hline J.S. Reynolds Comm. College & & Chemistry & 1 & J. Martin \\
\hline Longwood College & & Physics & 2 & L. Fawcett \\
\hline Lynchburg College & * & Chemistry & 16 & N. Summerlin \\
\hline Mary Washington College & * & $\begin{array}{l}\text { Physics } \\
\text { Physics }\end{array}$ & $\begin{array}{l}7 \\
1\end{array}$ & $\begin{array}{l}\text { R. Atalay } \\
\text { G. King }\end{array}$ \\
\hline Piedmont Va. Comm. College & * & $\begin{array}{l}\text { Physics } \\
\text { Physics } \\
\text { Physics }\end{array}$ & $\begin{array}{l}6 \\
1 \\
4\end{array}$ & $\begin{array}{l}\text { R. Bration } \\
\text { J. Waa'ipole } \\
\text { T. Lowe }\end{array}$ \\
\hline Randolph Macon College & & Physics & 1 & W. Temple \\
\hline Randolph Macon Women's College & & Physics & 2 & B. Mattson \\
\hline Roanoke College & & $\begin{array}{l}\text { Physics } \\
\text { Physics }\end{array}$ & $\begin{array}{l}1 \\
1\end{array}$ & $\begin{array}{l}\text { W. Baldridge } \\
\text { J. Adams }\end{array}$ \\
\hline Shepherd College & & Chemistry & 1 & W. Crum \\
\hline S.W. Va. Community College & & Chemistry & 2 & R. Epling \\
\hline Sweetbriar College & & Chemistry & 8 & H. Gager \\
\hline University of Richmond & & $\begin{array}{l}\text { Physics } \\
\text { Physics }\end{array}$ & $\begin{array}{l}1 \\
1\end{array}$ & $\begin{array}{l}\text { W. Major } \\
\text { M. Vineyard }\end{array}$ \\
\hline Virginia Commonwealth Univ. & * & Physics & 2 & S. Herr \\
\hline Virginia Military Institute & & $\begin{array}{l}\text { Chemistry } \\
\text { Chemistry } \\
\text { Physics } \\
\text { Psychology }\end{array}$ & $\begin{array}{l}2 \\
5 \\
2 \\
1\end{array}$ & $\begin{array}{l}\text { R. Minnix } \\
\text { H. Schreiber } \\
\text { P. Peters } \\
\text { D. Foster }\end{array}$ \\
\hline Virginia Tech. & * & $\begin{array}{l}\text { Physics } \\
\text { Env.\&Haz.Mat. }\end{array}$ & $\begin{array}{r}14 \\
1\end{array}$ & $\begin{array}{l}\text { T. Parkinson } \\
\text { D. Orvos }\end{array}$ \\
\hline College of William \& Mary & & Marine Science & 3 & J. Warinner \\
\hline
\end{tabular}

* These institutions and faculty members participated in the Reactor Sharing Program during the current and/or previous contract year.

Additionally, numerous high school groups have toured the facility and some of these have also participated in simple laboratory exercises. In the 1990-91 contract year, 474 primary and secondary school students and their teachers visited the reactor. 
TABLE ॥

EXPERIMENTS PERFORMED FOR THE UNIVERSITY OF VIRGINIA

REACTOR SHARING PROGRAM

\section{A. RADIATION AND RADIOACTIVE DECAY OF ISOTOPES}

\section{Radiation Counting Statistics}

Demonstration of the random nature of radioactive disintegrations at both low and high disintegration rates. Using a multi-scaler, series of counts are taken which, respectively, approach a Poisson distribution and a Gaussian distribution.

\section{Radioisotope Decay and Half-Life Determination}

Demonstration of radioactive decay and determination of reactor produced, short-lived isotope half-life using a multi-scaler. More complex decay chains may also be demonstrated, such as decay of two isotopes with differing half-lives or decay of two isotopes, one of which decays to the other.

\section{Types of Radiation}

Characterization of different types of radiation including determination of alpha and beta energy spectra using silicon surface barrier devices and gamma spectra using either a sodium-iodide scintillator or a germanium detector. Effectiveness of shielding materials for the various radiation types may also be demonstrated.

\section{Radiation Intensity and Shielding}

Demonstration of the decrease in radiation intensity as a function of the inverse square of distance from the radiation source. Determination of source activity from measured dose rates and radiation energy. Effectiveness of radiation shields may also be included.

\section{Gamma-Gamma Coincidence Techniques}

Demonstration of angular correlation of gamma rays from cobalt60 and of annihilation radiation from sodium-22. The absolute activity of sodium-22 may also be determined.

\section{Binding Energy of Last Neutron in Deuterium and Mass of} Neutron

Measurement of the energy of the hydrogen neutron capture gamma ray yields the binding energy of the neutron and allows the calculation of the mass of a neutron. 
TABLE II (continued)

B. RADIOISOTOPE APPLICATIONS IN SCIENCE AND INDUSTRY

1. Neutron Activation Analysis

Demonstration of trace element analysis using neutron activation analysis. A sample is activated in the UVAR and its constituents determined from the nature of its radioactive decay. Activation analysis of a coin, lipstick, hair, environmental samples, or other samples may be performed.

2. X-Ray Fluorescence Analysis

Demonstration of the chemical analysis of thin samples using an Am-241 x-ray exciter source and a germaniurn-lithium low-energy photon spectrometer. The $x$-ray spectrum measured from the material is used to determine the chemical composition of the surface.

3. Industrial Applications of Radioisotopes

Demonstration of the use of radioisotopes in industrial applications, such as thickness gauging, liquid level sensing and flow detection. Beta, gamma and neutron sources are used.

C. REACTOR EXPERIMENTS

1. Approach to Critical

Demonstration of the subcritical multiplication of neutrons until a self-sustaining fission reaction is obtained.

2. Reactor Dynamics and Safety Systems

Demonstration of changes in reactor power resulting from control rod position changes. Calibration of control rods and demonstration of reactor safety systems.

3. Decay Heat Following Reactor Shutdown

Measurement of heat generation from fission and fission product decay following a reactor shutdown. Measurements are read from nuclear instrumentation and calculated from primary system heat balance. 


\section{B.2. Research Projects for the Reactor Sharing Program}

A second objective of the Reactor Sharing Program is to offer the UVAR nuclear reactor and counting facilities for general use in research projects. For example, some experiments are been performed to determine the effects of radiation on materials. However, the major is in the area of neutron activation analysis (NAA).

Neutron activation analysis is a method of determining the elemental composition of a sample by placing it in the neutron flux of a nuclear research reactor. The neutrons interact with elements in the sample, transforming a small fraction of these into radioactive isotopes. The quantity of isotopes produced is established by the amount of each element present in the sample, the level of the neutron flux, and the irradiation time.

Once produced, each radioisotope emits characteristic gamma- rays by which the elements in the sample can be identified. When the sample is counted on sensitive solid state radiation detectors, the precise amount of each element can be determined.

At the University of Virginia we are currently able to analyze samples for over 50 different elements. This analysis is expedited by the use of dedicated computers which calculate the elemental composition directly from the gammaray spectra, sa.nple mass and irradiation conditions.

Over the last eleven years, many professors and students from various universities have carried out research projects utilizing the Reactor Facility. In most cases, the experimenters are not familiar wrii activation analysis techniques and depend on the reactor staff for advice on sample preparation, 
NAA procedures, data reduction and analysis. In a number of instances samples are supplied to the staff by the experimenters in bulk form. Starting from this, the entire analysis procedure is done by one or more staff members. The results returned to the experimenters state the elemental concentrations found in the supplied samples.

In the current contract year several universities indicated their intertion to begin projects utilizing Reactor Sharing funds, and two have done so as of this time. Scheduled but not yet completed projects for this year include additional work for Virginia Tech and James Madison University and a new project with Longwood College. Additional projects may be started if we are approached and asked for assistance. It is important to note that the sole funding received for these outreach services by the University of Virginia comes from the DOE Reactor Sharing Program. Thus, the continuation of these projects would be affected if Reactor Sharing funds were not available to cover the cost of the support.

A final report entitled, "Participation in the United State Department of Energy Reactor Sharing Program," which covers the program from 1990-1991 was issued in December 1991. A report for the 1991-1992 year will be issued late in 1992. 


\section{AVAILABILITY OF REACTOR}

The University of Virginia Reactor (UVAR) is issed extensively for research and training to support the educational programs at the University of Virginia, including the Reactor Sharing Program. Potential users have always been able to perform experiments due to the availability of the reactor. Given the high priority placed on this program, the UVAR and related facilities will continue to be available for use by user institutions as projected in this proposal. 


\section{POTENTIAL USER INSTITUTIONS}

There are over 50 colleges and universities located within a one day's trip radius from the University of Virginia which may benefit from the Reactor Sharing Program support. Institutions with programs in engineering, biology, physics, chemistry or other related sciences are listed in Table III. Users from universities Iscated outside of this area are also encouraged to participate in this program. Those which have are listed in Table III.

Several methods will continue to be used to inform potential users of the Reactor Sharing Frngram. First, letters describing the program are sent to department chairman in Anthropology, Biology, Chemistry, Environmental Science, General Science, Geology, Marine Science, Medical Technology and Physics at each of the colleges ar.I universities listed in Table III. Former participanis indicate that they learn of the prograi.i existence as a result of such letters. The next mailing is planned for the Spring of 1991.

Additionally, our staff or faculty publicize the program at professional meetings. Members of tour groups from colleges and high schools are encouraged to return singly to the facility at a later date to initiate independent research projects of their own design. Also, professors with whom periodic contact is maintained are invited to use our facilities for their unsupported research. The support of unfunded research through the Reactor Sharing Program often enables researchers to later apply' for and obtain grant money from other sources. 
TABLE III

A. Institutions Which Have Participated in the Reactor Sharing Program at UVA (through March 1992)

Bridgewater College
College of William and Mary
Emory and Henn College
Hampton Institute
Hampton-Sydney College
Indiana University
James Madison University
Longwood College
Luther College
Lynchburg College
Mary Washington College
Norfolk State University
Old Dominion University
Randolph-Macon College
Randolph-Macon Women's College
Roanoke College
Sweet Briar College
University of Richmond
University of South Carolina
Virginia Military Institute
Virginia Polytechnic Institute
Virginia State University
Washington and Lee University

B. Other Institutions Located Near UVA
Bridgewater, VA

Williamsburg, VA

Emory, VA

Hampton, VA

Hampton-Sydney, VA

Bloomington, IN

Harrisonburg, VA

Farmville, VA

Decorah, IA

Lynchburg, VA

Fredericksburg, VA

Norfolk, VA

Norfolk, VA

Lynchburg, VA

Lynchburg, VA

Salem, VA

Swee! Briar, VA

Richmond, VA

Columbia, SC

Lexington, VA

Blacksburg, VA

Petersburg, VA

Lexington, VA
Danville, VA

Bluefield, VA

Newport News, VA

Wise, VA

Harrisonburg, VA

Ferrum, VA

Fairfax, VA

Hollins, VA

Lynchburg, VA

Staunton, VA

Radford, VA

Ashland, VA

Richmond, VA

Bristol, VA

Richmond, VA

Norfolk, VA 


\section{E. ASSESSMENT OF USER INSTITUTION INTEREST}

The success of the Reactor Sharing Program in previous years, as discussed in section $B$, is the best indicator of user institution interest in the continuation of the program. Current interest is indicated requests for information or letters of appreciation for work performed which have been received by us, fourteen of which are included as Attachments $A$ through $N$. For a complete listing of past participants, please see the final report on participation in the program for the period September 1990 - August 1991.

\section{F. PERSONNEL}

The project director is Dr. R.U. Mulder, Director of the Reactor Facility (50\% time dedication) and Assistant Professor of Nuclear Engineering (50\% time). In his functions, Mulder is responsible for increasing reactor utilization in support of educational and research programs, upgrading of the Reactor Facility, teaching undergraduate and graduate nuclear engineering courses and conducting research programs.

Paul Benneche is the Reactor Services Supervisor at the University of Virginia. Previous positions held at UVA over the last 14 years include: Reactor Operations Supervisor, Research Engineer and Serior Reactor Operator. Benneche earned both BS('75) and MS('82) degrees at UVA in nuclear engineering. Areas of interest include neutron activation analysis, environmental monitoring and reactor utilization. 
Bouvard Hcsticka is a Research Scientist at the Nuclear Feactor Facility at the University of Virginia. He received his B.S. degree (nuclear engineering) from the Inniversity of Virginia in May 1986. Previously, he has also been employed by the Reactor Facility as a reactor operator and senior reactor operator. Prior work experience includes eight years in various capacities aboard nuclear submarines. Current research interests include neutron fluoroscopy, neutron shielding, neutron activation analysis and neutron-induced lattice defects. 


\section{G. ESTIMATED BUDGET}

This proposal requests approval of $\$ 9,010$ or the program in 1992-93.

The requested contract period is from September 1, 1992 to August 31, 1993.

The basis for the estimated budget is:

Personnel cost for technical assistance:

Bouvard Hosticka, $10 \%$ of effort for 12 months

Reactor use:

3,500

(a) Activations for research projects

20 hours of irradiation at $\$ 50.00$ per hour

( $1 / 2$ normal rate, reactor time shared

with other projects)

1,000

(b) Experiments for class experiments

5 hours of irradiation at $\$ 50.00$ per hour

(1/2 normal rate, reactor time shared

with other projects)

250

(c) Gamma ray spectrographic analysis of samples

(equipment use only, personnel cost already

covered). 100 samples at $\$ 22.50$ average per sample

( $\$ 5$ for irradiation equipment use, $\$ 10$ for

use of analysis equipment, $\$ 7.50$ per hour for

detector use.)

2,250

Clerical assistance:

200

(a) Report generation and mailing

100

(b) Production and mailing of information to potential user institutions

New funds requested for 1991-92

$\$ 9,010$

The personnel costs covers the direct effort necessary to prepare for and conduct experiments for classes and to assist in neutron activation analysis for research projects, as discussed in section B.

The reactor use charges are based on the presently established rate for reactor operation and covers all expenses associated with sample preparation, irradiation and use of equipment for subsequent counting for class experiments. 


\section{ATTACHMENTS}




\section{VIRGINIA POLYTECHNIC INSTITUTE AND STATE UNIVERSITY}

Blacksburg, Virginia 24061-0211

DEPARTMENT OF CHEMICAL ENGINEERING (703) 231.6631

April 24, 1990

Mr. Paul E. Benneche

Dept. of Nuclear Eng.

University of Virginia

Reactor Facility

Chariottesville, VA 22903-2442

Dear Paul,

In compliance with the first provision of the Memorandum of Understanding regarding participation in the Reactor Sharing Program, this letter describes my research project and the services desired from the UVA Reactor Facility. The goal of this research is to perform a numerical simulation of cooking extrusion in a single screw extruder using a wheat flour dough. Cooking extrusion is a process which is used in the manufacture of a variety of food products such as texturized vegetable protein, breakfast cereals, snack foods, and quick-cooking pasta products.

A key element in the experimental verification of the numerical computations is the measurement of residence time distribution (RTD) in the extruder. An effective method for measuring the RTD in a food extrusion process is to inject $\mathrm{MnO}_{2}$ as a tracer at the feed end of the extruder and then to collect samples of extrudate from the discharge end over an appropriate time period. Neutron activation analysis of these samples provides a measure of the manganese content, and the RTD can be derived from this information.

The services desired for this project include neutron irradiation and gamma ray spectrographic analysis. I anticipate that approximately 250 samples will require analysis. The personnel who will be involved are Donald G. Baird, Professor of Chemical Engineering at VPI\&SU and principal investigator on the project, and myself.

Sincerely,

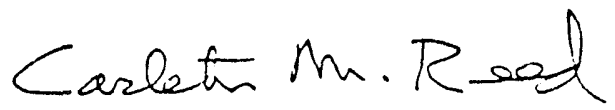

Carleton M. Reed

Graduate Student

cc: D. G. Baird 
Department of Environmental Sclences - Cook College

P.O. Box 231 - New Brunswick - New Jersey 08903-0231 - 908/932-9185 - FAX: 908/932-8644

$$
\text { January 9, } 1991
$$

Paul Bennecha

University of Virginia

Dept. of Nuclear Engineering and Engineering Physics

Nuclear Reactor Facility

School of Engineering and Applied Science

Charlottesville, Va 22903

Dear Mr. Bennecha:

This letter is to inform you that $I$ will be sending a small quantity of soil, roughly $10 \mathrm{Kg}$, to be sterilized at your facility as per our conversation, 1/4/91. It is my understanding that a minimum of 2 Megarads is necessary to achieve complete sterilization. If you have any questions please feel free to contact me at (908) 932-9082.

Thank you,

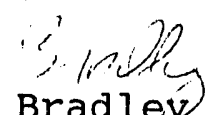

Bradley c. Williams

Research Scientist 


\section{BRIDGEWATER COLLEGE}

April 10,1991

Dr. Paul Benneche

University of Virginia

Dept. of Nuclear Engineering and Engineering Physics

Reactor Facility

Charlottesville, VA 22901

Dr. Benneche:

Thank you for accommadating the group of 6 physics students from Bridgewater College on April 4, 1991. Although the students had no previous experience in nuclear physics, they expressed to me that they had an enjoyable as well as an informative experience. The neutron activation experiment the students performed while at your facility provided an opportunity to do research that otherwise would not have been available to them. Again thank you for sharing your facility and time with us.

Sincerely,

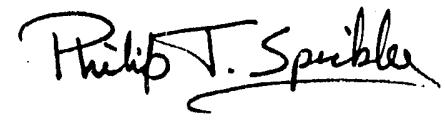

Philip T. Spickler Instructor in Physics 
Apri1 30,1991

F'ani Ennmehe

Dept. of Nuclear. Engineering

Ereireerine Physics

Fator Facility

Univereity of Virginia

arretotiontle. VA 22001

Yat.1.1.2.

$(4)$

T.". no now andes are to be given doses as marked (0.2-1.0 MR)

a bu whe we (. avk/hr). I think these should be the last

and the study. Thanks for your cooperation.

Hats resards.

thin mo 


\section{N V I R G I N'I A}

1501 LAKESIDE DRIVE:

LYNCHBIIRG, VIRCIINIA 2ASIU1:3IU!!

(80). $1522 \cdot 8100$

Hay 8,1991

lir. Bouvard Hosticka

Department of Huclear Engineering

Reactor Facility

University of Vircinia

Charlottesville, VA 22901

Dear Bo:

Thanlss much for running the neutron activation analysis lab for ny nuclear chemistry class last Friday. They enjoyed it, and I got several positive comments on the amount of useful information you provided in a relatively short period of time. Even that limitea dmolint of "hands-on" experience is helpful for students.

On a separate matter. I'm afraid the cost of 30 L of liquid nitrogen per veek is just too much for us to pay, especially for an instrument that would get limited use. I very much appreciate the offer, hoverer, and any time you have a $15 \%$ efficient intrinsic germanium detector you vant to dump, let me know!

Tentative date for bringing anywhere from ten to fifteen high-school students up is Thursday, July 25 th. I'li get back with confirming details as the time draws nearer.

Thanks again!

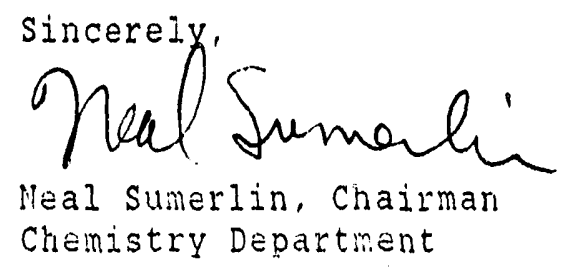




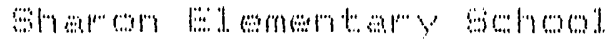

10.4.

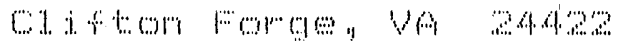

$\because, 12,91$

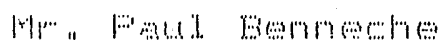

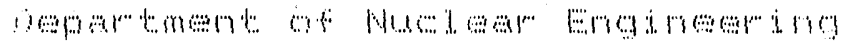

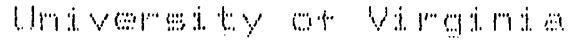

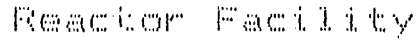

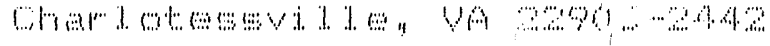

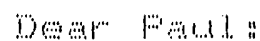

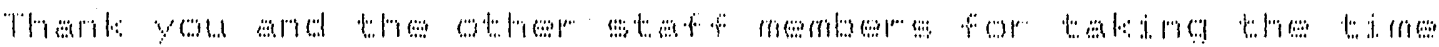

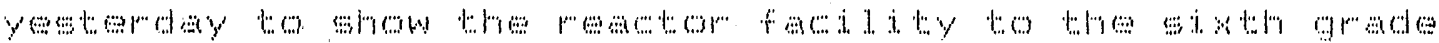

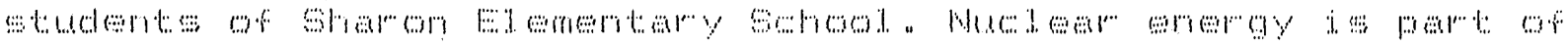

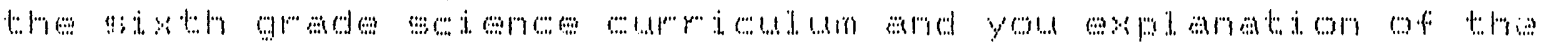

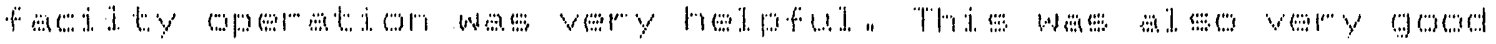

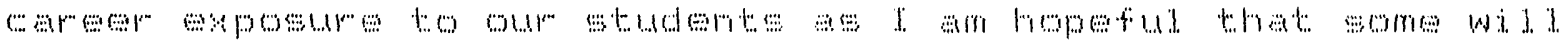

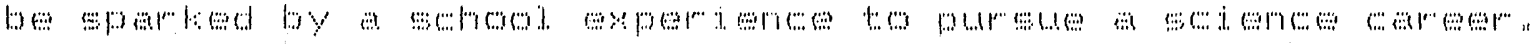

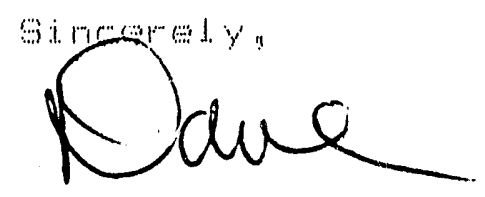

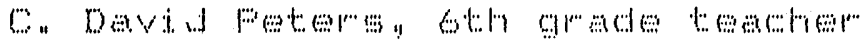




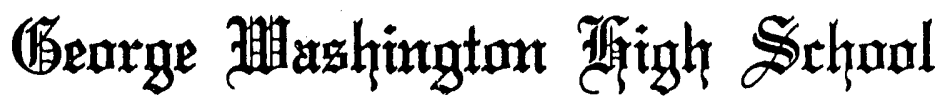

\section{Bamille, 唒irginia 24541}

\section{DFFICE OF THE PRINCIPAL}

May 27,1991
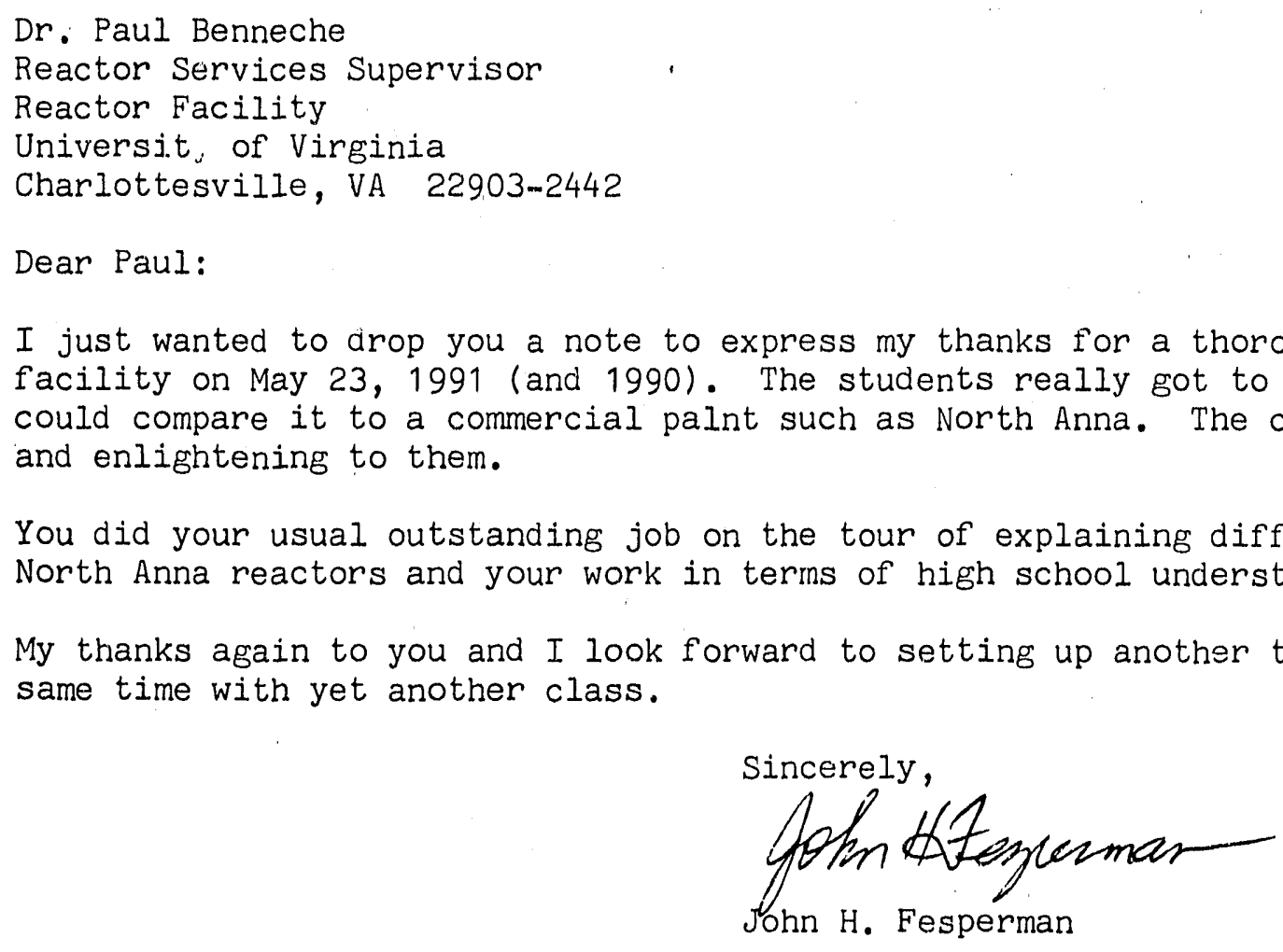


\title{
WOODBERRY FOREST SCHOOL \\ WOODBERRY FOREST, VIRGINIA 22080
}

(703) 672.3900

\author{
Lewis Acampora \\ Science Department \\ Woodberry Forest School \\ Woodberry Forest, Va. 22989 \\ 29 July 1991
}

Mr. Paul Benneche

Nuclear Engineering Reaction Facility

University of Virginia

Charlottesville, Va. 22903

Dear Mr. Benneche:

I want to thank you personally and on behalf of the students of our chemistry and physics classes for hosting our visit to the reactor and giving us a very educational tour. The field trip proved to be an excellent break from our daily routine, and the students were fascinated by seeing the "reality" of a nuclear reaction faciliiy--it is certainly much different than many of them would have pictured!

Thank you especially for taking the time to be so accomodating to such a large group. It is wonderful to be able to take advantage of the opportunities afforded by the University, and I am thankful that you made it so easy for us to do so. Good luck with your research, and I hope to see you with future groups.

Sincerely yours,

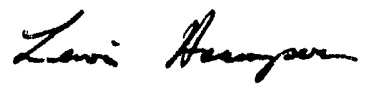

Lewis Acampora

Science Department

Woodberry Forest School 
MAJOR WLLIAM A CHICK, CAP

125 FOEESTVWE DeTVE

ENTYSTIIIE, VA 22966

(804) 973-8869

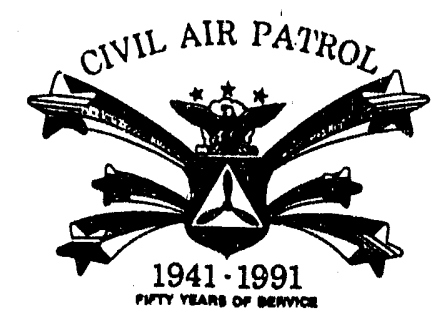

Appendix I

GROUP || campr prosenars PURLIC AFFATRS

REACTOR ADMINISTRATOR

UNIVERSITY OF VIRGINIA

NUCLEAR REACTOR FACILITY

CHARLOTTESVILLE, VA 22903-2442

AUG 20, 1991

MR I P FERRAR,

We thank you and your staff for given us a tour of your facility for the 35 Civil Air Patrol Cadets who were in the area for their annual training.

They all seem to enjoy the visit. We heard about the GLOW for some time after we departed.

We appreciate you supporting our young people.

Thanks again.
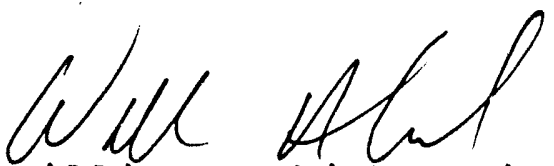

William A Chick, Major, CAP

Project officer 
Tech

VIRGINIA POLYTECHNIC INSTITUTE

AND STATE UNIVERSITY

\section{Department of Entomolog}

College of Agriculture and Life Sciences Blacksburg, Virginia 24061-0319 USA (703) $231-6341$ Fax: (703) 982-6050

Bitnet: ent4@vtvm!

1 December 1991

Dr. Paul Benneche

Department of Nuclear Engineering

Reactor Facility

University of Virginia

Charlottesville, VA 22903

Dear Paul:

I would appreciate it if you could sterilize the four containers that I have sent you in the styrofoam cooler. Each vessel contains 4.0 microcuries of 14C-ringlabelled atrazine, $10 \mathrm{~g}$ of peat moss, and approximately $0.5 \mathrm{ug} / \mathrm{g}$ atrazine. Two of the vessels are bottles which I imagine will not be difficult to sterilize, however, the other two vessels are specially constructed glassware for the experiment. They are less than 2.5 inches in diameter, and I hope that they fit in the reactor. Please, contact me if there is a problem.

There is no particular urgency to sterilize these vessels and get them back to me. If, however, it is longer than a day after you receive them, could you keep them cold $\left(<4^{\circ} \mathrm{C}\right)$ until you get to them? Afterwards, you do not need to keep them refridgerated or need to pack them on ice or dry-ice for the trip back to Virginia Tech. Please send them to me care of:

Doug Smiley, Radiation Safety, Room 104, Health and Safety Bulding \#459, Virginia Tech, Placksburg, VA, 24061.

I do appreciate the service that you and your Department provide, and in future articles corresponding to research with the sterilized vessels, your services will be mentioned with my pleasure. Please inform me of any instructions that would make future packages for sterilization easier for you.

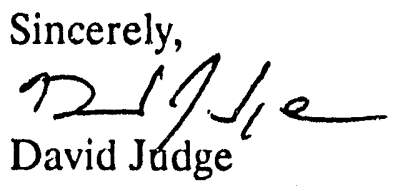

encl. 4 glass vessels containing 4.0 microcuries of $14 \mathrm{C}$-atrazine in $10 \mathrm{~g}$ peat moss with $0.5 \mathrm{ppb}$ unlabelled atrazine.

cc. Doug Smiley

Donald Mullins 


\title{
I N V I R G I N I A
}

1501 LAKESIDE DRIVE

LYNCHBUIRG, VIRGINIA 24501:31999

(804) 522.8100

\author{
December 14, 1991
}

Mr. Bouvard Hosticka

Department of Nuclear Engineering

Reactor Facility

University of Virginia

Charlottesville, VA 22901

Dear Bo:

Thank you once again for the opportunity afforded my students by the Reactor Sharing Program at UVa. My nuclear chemistry class very much enjoyed getting to see equipment they had learned about in class. I imagine that we will both be certain that sight is the only sense involved the next time we learn about thin beryllium windows!

Thanks again for your significant contribution to our educational program.

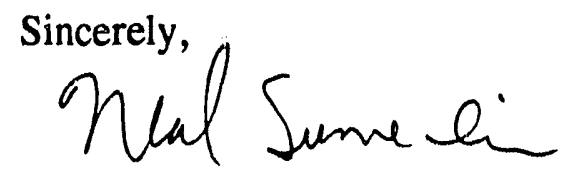

Neal Sumerlin, Professor and Chairman

Chemistry Department 


\title{
Virginia Commonwealth University
}

\author{
Paul Benneche \\ Reactor Services Supervisor \\ University of Virginia \\ Department of Nuclear Engineering \& Engineering Physics \\ Reactor Facility \\ Charlottesville, Virginia 22093-2442
}

January 28, 1992

Dear Dr. Benneche,

I wish to thank you and the Reactor Facility staff for the tour and laboratory experiment/demonstration provided for my Modern Physics Laboratory students on November 22, 1992. The students thoroughly enjoyed the entire program and, judging from their enthusiasm and general interest, found it to be a real educational experience.

The faculty in the VCU Physics Department is made up largely of solid state physicists and there is no ongoing research in the area of nuclear physics. The Reactor Sharing Program at UVA provides an excellent opportunity for VCU students to gain a hands on look at nuclear physics and broaden their scope of physics research. I feel that this is an outstanding program and have incorporated a tour of the reactor facility into my Modern Physics Laboratory course syllabus as a required field trip.

Thank you again for your cooperation and hospitality, I hope to see you again next fall.

Sincerely,

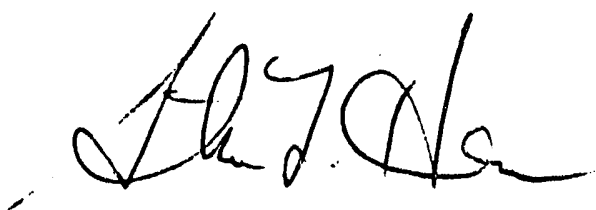

Steven L. Herr

Assistant Professor 
Bo Hostika

Nuclear Reactor Facility

University of Virginia

Charlottesville, Va

\section{Dear Bo:}

I am writing to express my appreciation for your conducting a tour for my nuclear chemistry class on Friday February 28. As always, you did a very good job and I am certain that the class found the tour very informative and educational. The reactor start up was particularly well received and I think the neutron activation analysis of selenium in horse hooves was a good way to demonstrate the value of a reactor in elemental analysis. As part of the course I require the students to conduct a project of their own design. You may recall, a few years ago one student irradiated soil samples for mercury analysis. Another project involved a study of the equilibrium between $\mathrm{Zr}-95$ \& 97 and daughters using reactor irradiated zirconium. I don't know if any projects this year will involve reactor irradiations, but if this is the case, I will call you to discuss to see if it is posisible for us to have some irradiation done and discuss the details.

Again, thank you for taking the time to give us the very good tour. I am sure that the students benefitted greatly by the opportunity to see a real reactor in operation.

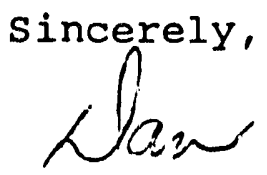

Daniel M. Downey, Ph.D. Associate Professor 


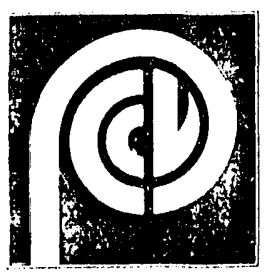

Bouvard Hosticka

Research Scientist

University of Virginia

Department of Nuclear Engineering

and Engineering Physics

Reactor Facility

Charlottesville, VA 22903-2442

Dear Bo,

On behalf of my Chemistry 111 students, as well as Rick and myself, I want to thank you for the tour of the University of Virginia Reactor Facility last week. We especially appreciate the special efforts that you made for us. Doing the tour in the evening and leaving the reactor operating beyond normal shut-down call for special thanks.

If you have printed information on experiments that could be done with students such as mine, I would appreciate having a copy.

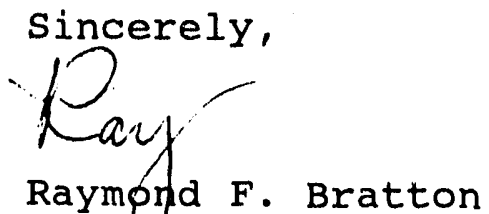

Professor of Chemistry

mw

Albemarle Charlottesville Fluvanna Greene Louisa Nelson 


\section{DISTRIBUTION LIST}

1-3* Department of Energy

Contracts Division

Chicago Operations Office

9800 South Cass Avenue

Argonne, IL 60439

Attention: Renee L. Irwin

Contract Specialist

4 Dr. Larry Barker, Program Manager

Office of University and Science Education Programs, ER-80

U. S. Department of Energy

1000 Independence Avenue, N. W.

Washington, DC 205:85

** SEAS Postaward Administration

5 - 6 R. U. Mulder

$7 \quad$ P. E. Benneche

8 B. Hosticka

9 A. B. Reynolds

$10-11 \quad$ E. H. Pancake

12 SEAS Preaward Administration

*1 Original, unbound \& 2 bound copies.

** Cover letter.

JO\#4468:ph 

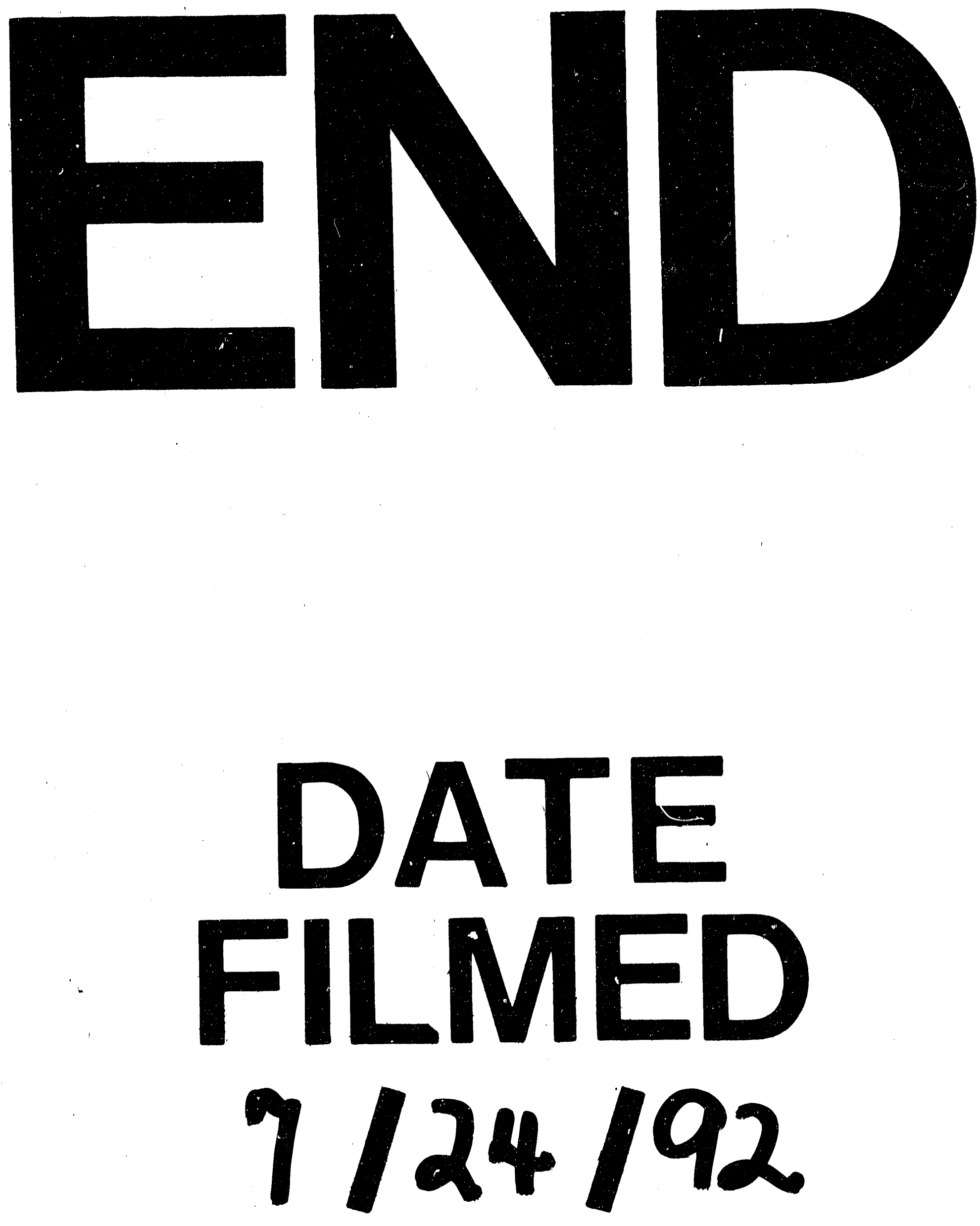
